(C) 1982 ISIJ

連続焼鈍によるリン添加高強度冷延鋼板の開発

\title{
Development of High Strength Cold-rolled-phosphorus Steel Produced by Continuous Annealing
}

\author{
Hiroshi Takechi, Hiroshi Katoli, Kazuo Koyama, \\ Kohichi KaWASAKI, and Hiromi Toyota
}

\begin{abstract}
Synopsis:
A high strength cold-rolled phosphorus-containing steel has been developed by continuous annealing prccess. The study is focussed on the improvement of Lankford value and aging characteristics of phosphorus-containing steel.

The effects of coiling temperature after hot rolling and cold reduction on Lankford value have been investigated for a low $\mathrm{G}$-low $\mathrm{Mn}-\mathrm{B}-\mathrm{P}$ steel. Investigations have also made clear the effects of cooling rate after continuous annealing on the precipitation rate and the size of precipitates of carbides. Experimental results show that (1) the combination of proper coiling temperature and large cold reduction results in high Lankford value over 1.5 and (2) the combination of high paint baking hardenability over $40 \mathrm{MPa}$ with retarded aging property at room temperature can be obtained in the range of cooling rate from 10 to $100 \mathrm{deg} \mathrm{C} / \mathrm{s}$. The factors affecting such results are also discussed.
\end{abstract}

\section{1. 緒}

\section{言}

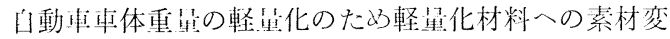
換が急速に進められている。この中で比較的容易に取り 入れることができ，印效が期待できるう法として，普通 鋼板の高強度鋼板一の転換がある. 自動車用高強度冷延 鋼板として現在，引張強さ $350 \mathrm{MPa}$ から $1000 \mathrm{MPa}$ 以上の種々の鋼板が開発されているが，このらち比較的 低強度で加工性がよく，目動車外板にも使われるもの子

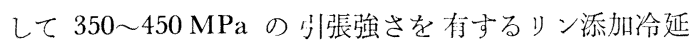
鋼板がある。リンは安偳でかつ非常に大きな罱換型固溶 体強化能を示す。さらに箱焼鈍した場合, 高いランクフ ォ一ド估（倠）を存することが知られている1)。この ため現在，箱焼鈍によるリン添加冷延鋼板が滴用鋼とし て，外板の耐デント性问上，内板の静的あるいは疲学強 度向上といった日的で多星に使用されるに至つている。

一方，冷延鋼板の製造才法として従来の電気清沵，箱 焼鈍, 調質压延, 検定といつた各工程を一まとめにした 冷延鋼板連続焼鈍設備が，生産性や品質の面から次々之 導入され，従来工程に取つて替わうらとしている22. 連 続焼鈍では普通鋼板の場合，材質面から少なくとも二つ
の考虑を払つている。一つは急速加熱，短時間焼鈍でも 十分な結品䊉成立と良好な集合組織が得られるように素 材もしくは前工程を調整することである，固溶 Mnの 低減，熱延高温巻き取り3)，ボロン添加4) などがこれに あたる、このうち高温卷き取りは連続燒鈍の前工程調整 として最も古くから採られている手法である.

冷延鋼板用連続焼鈍の特徵のもら一つは，冷延鋼板に とつて重要な時效性低減のため, その要因となる固溶炭 素・窒素を減少させる手段を講じていることである、窒 索については窒化アルミニウムあるいはその他の窒化物 として固定させる．岑素については焼鈍後の急冷，過時 効処理によつて岑化物として析出させる. この冷却, 過

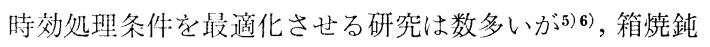
材並の非時効性を得ることは極めて困難である.

リン添加鋼を連続焼鈍で製造する場合, 上述した連続 燒鈍の二つの特徵それぞれに関連した問題があるＦi.g 1 は高湍巻き取りの $\bar{r}$ 值向上効果をアルミキルド鋼とり ン添加アルミキルド鋼とで比較した図である. 図からわ かるようにリン添加鋼の場合, $750^{\circ} \mathrm{C}$ の高温巻き取りを 施しても $\bar{r}$ 值はそれほど向上せず，深絞り用鋼板として 必要な 1.5 に達しない。亦た, 炭素時効に関するリンの

昭和 56 年 4 月本会講演大会にて発表 炤和 56 年 10 月 20 日受付 (Receivep Oc. 20, 1981)

* 新日本製鉄 (株) 君津製鉄所 (現：分幡製鉄所）工博 (Kimitsu Works, Now Yawata Works, Nippon Steel Corp.)

*2 新日本製鉄(株)君津製鉄所工博 (Kimitsu Works, Nippon Steel Corp.)

*3 新日本製鉄(株)热津製鉄所 (Kimitsu Works, Nippon Steel Corp., 1 Kimitsu Kimitsu 299-11) 


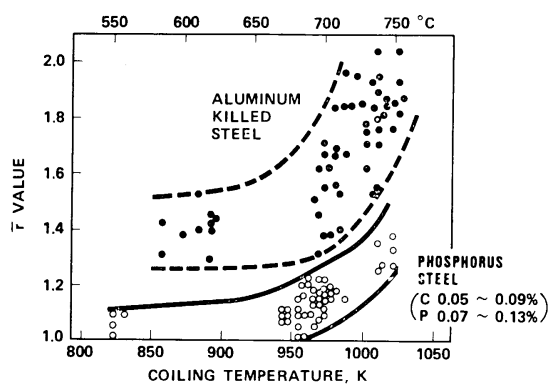

Fig. 1. Coiling temperature dependency of $\bar{r}$ value of phosphorus steel and aluminum killed steel.

影響を調べた研究も少なく，したがつてりン添加鋼にお ける最適な冷却, 過時効条件は求められていないといえ る.このように箱焼鈍においては製造技術的に確立して いるリン添加鋼も，連続焼鈍においてはいまだ十分な特 性の鋼板は得られていない.

本報では，低 G-低 Mn-B をベース成分としたリン 添加鋼に打いて熱延条件，冷延压下率，焼鈍温度を考虑 することで高 $\bar{r}$ 值が，連続焼鈍の冷却条件を最適化する ことで革時効, 良加工性といら特性が得られることが判 明したので，以下詳細に報告する。

\section{2. 実 験 方 法}

$0.015 \mathrm{C}-0.10 \mathrm{Mn}-0.070 \mathrm{P}-0.031 \mathrm{Al}-0.0021 \mathrm{~B}$ 鋼 $(\mathrm{B} / \mathrm{N}=$ 0.70)を転炉出鋼し連続鋳造にて鋼片としたのち実機に よる熱間圧延を行つた，成分的に低 C-低 Mn として粒 成長性を促がし低降伏比，高 $\vec{r}$ 值を致らつたが，低 $\mathrm{C} に$ よる焼鈍後冷却時の過飽和度減少のため固溶炭素が残存 し，その結果として時効劣化が眯念される. ボロンは窒 素固定の意味であり，窒素量が約 $25 \mathrm{ppm}$ でめることか らボロン量は窒素との原子等量に近い $20 \mathrm{ppm}$ とした. 熱間压延の条件としては加熱温度を $1100^{\circ} \mathrm{C}$ と実機と しては低くし，仕上げ圧延終了温度は 880 900 $\mathrm{C}$ と し，続いて巻き取り温度を $600,700,750^{\circ} \mathrm{C}$ と変化さ せて巻き取つた．熱延鋼板の厚みは $4.0 \mathrm{~mm}$ とした。

実験 I 冷延圧下率と $\bar{r}$ 值の関係

この鋼の $\bar{r}$ 值におよぼす冷延圧下率の影響を調べるた めに熱延板を採取し，平面研削で種々の嬮みまで薄くし たのち実験室圧延機で $0.6 \mathrm{~mm}$ まで冷延した. 冷延圧下 率は $40 \sim 85 \%$ に変化させた。焼鈍はソルトバスを用 い，その条件はFig. 2 に示すとおりである。

実験 II 時効性におよぼす連続焼鈍後冷却条件の影響 上述のよらにして製造した熱延板を実機にて $0.8 \mathrm{~mm}$ の冷延板（冷延圧下率 80\%）にして試料を採取した. この冷延板を連続焼鈍シミュレーターにて焼鈍した.シ

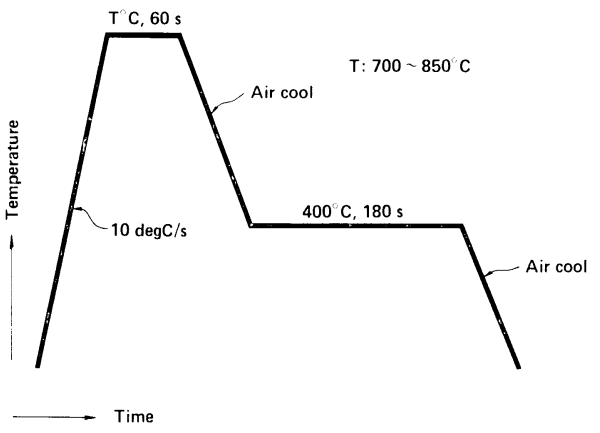

Fig. 2. Heat cycle of simulated continucus annealing in order to reveal the effect of cold reduction on $\bar{r}$ value.

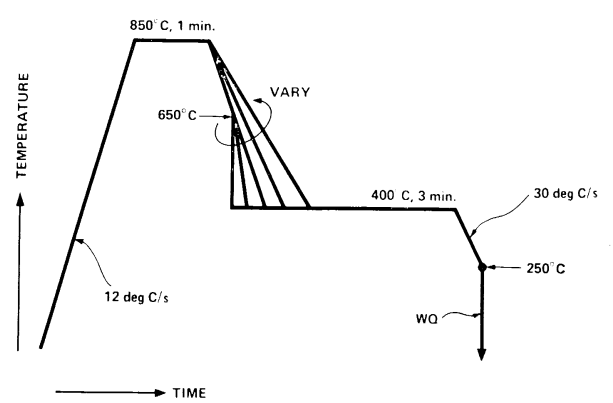

Fig. 3. Heat cycle of simulated continuous annealing in order to reveal the effect of cooling rate on aging properties.

ミュレーターは石英ガラス管队で赤外綠加熱するお式 で，冷却は管端のノズルから水またはガスの噴射による か，もしくは管外に案内して水またはガスの噴射ないし は各種冷媒に浸漬して行う. 過時効のためのシェルフ処 理を㷙提とした場合でも $1 \sim 150 \mathrm{deg} \mathrm{C} / \mathrm{s}$ の範囲で泠却速 度が制御できる。な扮却速度がこの筙用を越える場合 はいつたん室温まで泠却したのち再加熱して過時効処理 を行つた. Fig. 3 に实験に用いたヒートサイクルを示 す. 冷却速度が大きい場合 $650^{\circ} \mathrm{C}$ 屯では $30 \mathrm{deg} \mathrm{C} / \mathrm{s} て ゙$ 冷却した。 また過時効後の冷却は $250^{\circ} \mathrm{C}$ までは $30 \mathrm{deg}$ $\mathrm{C} / \mathrm{s}$ で冷却した.

引張試験は圧延方向のみとし，50 mm × $300 \mathrm{~mm}$ の熱 処理試料の中央部をJIS 5 号試験片に加工した. 原則的 に 1 実験点は繰り返し数 3 の平均で示した。 通常の引張 試験の他に叙装焼付硬化性を表す BH 性 (Bake Hardenability) の試験も行つた. $\mathrm{BH}$ 性は $2 \%$ 引張ひずみ を与えたのち $170^{\circ} \mathrm{C}, 20 \mathrm{~min}$ の熱処理を行い，この熱 処理による降伏点上昇代 (BH 量), もしくは処理後の 降伏点応力 $(\sigma 2 \%+\mathrm{BH})$ で示される. 引張試験の他に内 部摩擦による国溶炭素の測定や, SPEED 法 (Selective 
Potentiostatic Etching by Electrolytic Dissolution Method) ${ }^{7)}$ による疢化物観察电行つた。

\section{3. 実 験 結 果}

\section{1 低 $\mathrm{C}-$ 低Mn-B-P 鋼の $\boldsymbol{r}$ 值におよぼす巻き取り温度 冷延圧下率の影響}

Fig. 4 飞冷延压下維と $\bar{r}$ 值との関係を示吉(焼鈍温度 $\left.850^{\circ} \mathrm{C}\right) .600^{\circ} \mathrm{C}$ 卷き収り材では冷延理下摔が 75〜80\% で $\bar{r}$ 值が较大となりこ机以上冷延压下率を增すと $\bar{r}$ 值は 劣化する。坄大 $\bar{r}$ 估は 1.6 程度でめる。こ北に対して $700,750^{\circ} \mathrm{C}$ の南滥炎き取り材では本笑験の籍四内（冷 延压下渗 85\% まで) で一様に $\vec{r}$ 值は增加している. 85 $\%$ 冷延の場合, $700^{\circ} \mathrm{C}$ 巻き收りで $\vec{r}$ 值が $1.8,750^{\circ} \mathrm{C}$ 巻き取りで 1.65 となる。

つぎに Fig. 5 に焼鈍温度と $\bar{r}$ 值の関係を示す。 600 , $700^{\circ} \mathrm{C}$ 巻き取り材をそれぞれ $80 \%$ 冷延し焼鈍温度を変

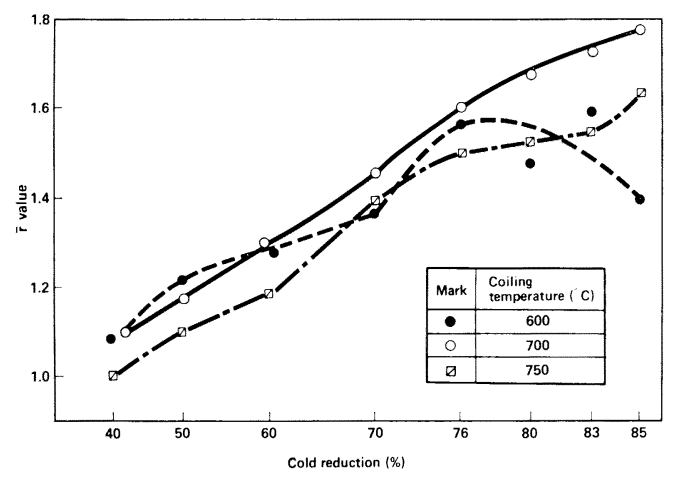

Fig. 4. Relation between cold reduction and $\bar{r}$ value of low C-low Mn-B-Phosphosus steel.

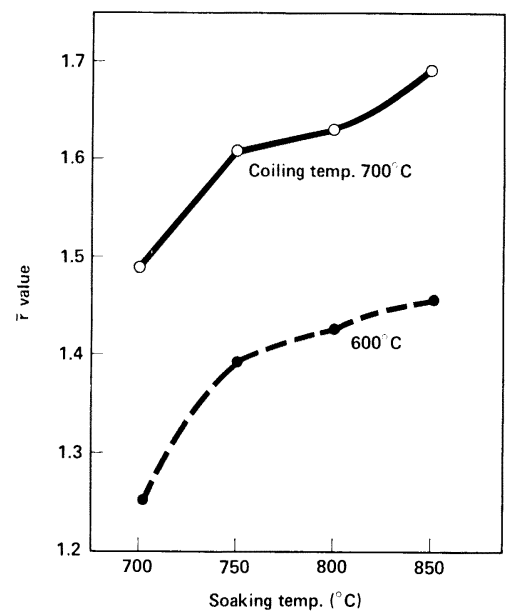

Fig. 5. Relation between soaking temperature and $\bar{r}$ value.
化させている。焼鈍温度の依存性は $750^{\circ} \mathrm{C}$ 以上では比 較的小さく, $750^{\circ} \mathrm{C}$ から $850^{\circ} \mathrm{C}$ に增しても $r$ 值の增加 は 0.1 以内である。束た巻き取り温度によつてこれら の傾向はあまり影響を受けない。

\section{2 低 C-低Mn-B-P 鋼における連続焼鈍後の冷却条}

\section{件之時効性との関係}

冷延鋼板の時效性としては stretcher-strain に面接結 びつく降伏点仰び (以下 Y P-El) の時効による回復がま ず問題となる。つぎにプレス成形の容易さを示す降伏点 (以下 Y P) や仲び值（以下 El）の時效による変化が問 题となる．Fig. 6 は焼鈍後過時效開始までの冷却速度 (ただし冷却速度が大きい場合には $650^{\circ} \mathrm{C}$ から過時効開 始までの冷却速度) と機械試験值との関係をプロットし た. 以下，この冷却速度を $V_{\mathrm{C}}$ と呼ぶこととする. 図 中， $\Delta \mathrm{YP}, \Delta \mathrm{El}$ はそれぞれ $100^{\circ} \mathrm{C}, 60 \mathrm{~min}$ の時効によ る YP の上昇代, El の劣化代を表わす.

時効後 $\mathrm{YP}-\mathrm{El}$ は $V_{\mathrm{C}}$ が $10 \mathrm{deg} \mathrm{C} / \mathrm{s}$ で実用上問題と ならない値となり, $V_{\mathrm{C}}$ が $40 \mathrm{deg} \mathrm{C} / \mathrm{s}$ 以上になると $\mathrm{YP}$ -E1 の回復はまつたくない。時効後 YP は低 $V_{\mathrm{C}}$ 側で は，時効劣化が大きく，高 $V_{\mathrm{C}}$ 側では調圧ままでの值 が大きいため， $V_{\mathrm{C}} \quad 10 \sim 50 \mathrm{deg} \mathrm{C} / \mathrm{s}$ で最小值を示す. ド アー, トランクリッドのような自動車大外板成形におい ては面ひずみの観点から Y P $250 \mathrm{MPa}$ 以下という条 件が提晿されているが8)，この点からすると YP は時効 後において $10^{3} \mathrm{degC} / \mathrm{s}$ に近い極度に大きい $V_{\mathrm{C}}$ をとら

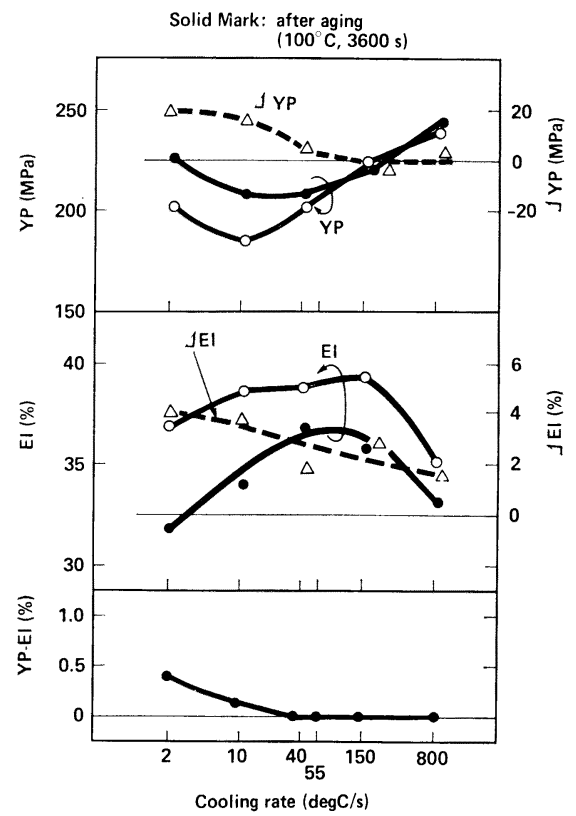

Fig. 6. Influence of cooling rate on mechanical properties of low C-low Mn-B-Phosphorus steel. 


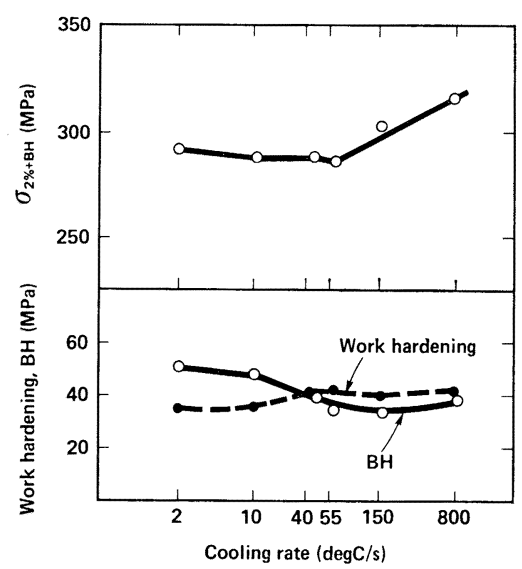

Fig. 7. Influence of cooling rate on $\mathrm{BH}$ properties.

ない限り許容值内とい方る，El は調王ままでは $V_{\mathrm{C}}$ の 10〜 102 deg C/s の範围でほぼ一定值を示すが時效後に おいては $V_{\mathrm{C}} 40 \sim 100 \mathrm{deg} \mathrm{C} / \mathrm{s}$ で琝大优を示す。 Y P お よび $\mathrm{El}$ がこのような傾向を示す理由については後で考 察する。

自動車パネル用鋼板の強度は前に述べたよらに $\sigma 2 \%+$ $\mathrm{BH}$ か $\mathrm{BH}$ 量で即伍すべきである. Fig. 7 に $V_{\mathrm{C}}$ とこ れら焼付硬化挙動の関係を示す。 $\mathrm{BH}$ 量は $V_{\mathrm{C}}$ の增加と ともに減少する㖽向にあるが，最小でも $40 \mathrm{MPa}$ 㐫り, 箱焼鈍材飞抢㺭る $20 \mathrm{MPa}$ 以下之いら值と比べると十分 大きい值である。これを $\sigma 2 \%+\mathrm{BH}$ でみると YP と同 じ傾向を示す．現状ではこの $\sigma 2 \%+\mathrm{BH}$ に対する要求值 は $280 \mathrm{MPa}$ といわれているが，この要求值はいずれの $V_{\mathrm{C}}$ に拈いて子満たす。

リン添加鋼の箱焼鈍材では BH 量が小さいため $\sigma 2 \%$ + BH を確保しようとすれば初期 YPを20〜30 MPa 增 す必要が生じ，プレス成形時に前述の面ひずみの問題が 起こる，これに対して低 $\mathrm{C}$-低 $\mathrm{Mn}-\mathrm{B}-\mathrm{P}$ 鋼の連続焼 鈍 材では， $V_{\mathrm{C}}$ を $10 \sim 100 \mathrm{deg} \mathrm{C} / \mathrm{s}$ にとる限り，時効を考 虑しても $\mathrm{YP}-\mathrm{El} \approx 0$, 低 $\mathrm{YP}$, 淌 $\mathrm{El}$ でから強度 $(\sigma 2 \%+\mathrm{BH})$ も確保できる。

\section{3 現場製造試験}

Table 1 に実機の連続焼鈍灯 (冷却はガスジェット力 式で $V_{\mathrm{C}}$ は約 $10 \mathrm{deg} \mathrm{C} / \mathrm{s}$ ) で焼鈍した材料の機械試験值 を示す。素材は実験 I，IIで用いた現場出鋼材で巻き取 り温度は $700^{\circ} \mathrm{C}$, 冷延圧下㳯は $80 \%$ である。狫鈍温度 は $850^{\circ} \mathrm{C}$ ，過時效温度は $400^{\circ} \mathrm{C}$, 調圧率は $1.2 \%$ で施 る。調圧ままで YP $200 \mathrm{MPa} ， \bar{r} 1.73$ と良加工性を示 し，かつ $\sigma 2 \%+\mathrm{BH}$ \& $320 \mathrm{MPa}$ と十分に高い。この鋼 板は 6 ヶ月自然時効後も YP-El は発生せず，YP, El
Table 1. Mechanical properties of newly developed steel sheets produced by actual mill.

As temper rolled

\begin{tabular}{ccccccc}
\hline $\begin{array}{c}\mathrm{YP} \\
(\mathrm{MPa})\end{array}$ & $\begin{array}{c}\mathrm{TS} \\
(\mathrm{MPa})\end{array}$ & $\begin{array}{c}\mathrm{EI} \\
(\%)\end{array}$ & $\begin{array}{c}\mathrm{YP}-\mathrm{HI} \\
(\%)\end{array}$ & $r$ & $\begin{array}{c}\mathrm{BH} \\
(\mathrm{MPa})\end{array}$ & $\begin{array}{c}\sigma 2 \%+\mathrm{BH} \\
(\mathrm{MPa})\end{array}$ \\
\hline 204 & 350 & 40 & 0 & 1.73 & 54 & 315 \\
\hline After 6 months & & & & \\
\hline $\begin{array}{c}\mathrm{YP} \\
(\mathrm{MPa})\end{array}$ & $\begin{array}{c}\mathrm{El} \\
(\%)\end{array}$ & $\begin{array}{c}\mathrm{YP}-\mathrm{El} \\
(\%)\end{array}$ & $\begin{array}{c}\mathrm{BH} \\
(\mathrm{MPa})\end{array}$ & $\begin{array}{c}\sigma 2 \%+\mathrm{BH} \\
(\mathrm{MPa})\end{array}$ \\
\hline 217 & 38 & 0 & 44 & 308 \\
\hline
\end{tabular}

の劣化代もわずかである。

\section{4. 考察}

\section{$4 \cdot 1$ リン添加鋼における $\bar{r}$ 值向上条件}

連続燒鈍のような急速加熱，短時間焼鈍で絞り性に良 好な結晶集合組織を得るには熱延板において同溶炭素, 空素のような不純物を極力減少させ，かつ結继粒界を増 すことが必要条件とされている99.このよらな純化効果 は，冷延集合組織を変觉ることで篮少しているのか10，

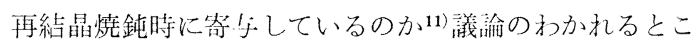
ろである。熱延高温巻き収りを行らと岑化物は凝集し， 塊状也メンタイトとなる。乞のため相対的に清浄なマ下 リックスを作りだすし，また焼鈍加熱時に岑化物が塊状 のため溶解しにくく清抙な状態で将絬晶が進行少る。こ のような純化效果として高浽灷取の放果が説明さ机てい る.

しかし通常のリン添加鋼の場命, Fig. 1 に示すように 高温巻き取りを施しても $\vec{r}$ 值は问上しない。このことは 松藤ら ${ }^{12)}$ も指摘している. Fig. 8 は $0.03 \%$ C-アルミキ ルド鋼において，リン旦を変化させたときの板面平行な 結晶面強度の变化をX線回折で求めた結果である。焼鈍 は $10 \mathrm{degC} / \mathrm{s}$ 加熱で $800^{\circ} \mathrm{C}$, 保定なしといら条件で行つ た. 熱延後空冷した材料は好ましい集合組織の発達を示 していない，高温巻き取り相当材の埸合，リン量が増 すにつれて 111 が減少し 100 が增加している、リンは

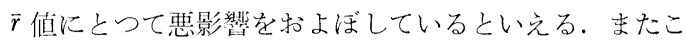
の場合，低温加熱の方が 111 が高く，100が低くなつ て扔り $\bar{r}$ 值にとつて好玉しい。リンは熱延板の結晶粒 界にクラスター状もしくは化合物として偏析するとい われ，この偏析が徐加熱，彭時䦗燒鈍の場合，好ましい 集合組織形成に寄与しているといわれている1)。急速加 熱短時間焼鈍では逆にこのりン偏析が粒界の変形の連続 性を減し糨界の $\{554\}\langle 225\rangle$ 核生場所としての作用を減 じていると考光られる。また低滥加熱の効果は加熱時の AlN 溶解を減らしてN 固定を果たす作用と低温熱延に 上る熱延板の細粒化といらことで就明される，以上から 


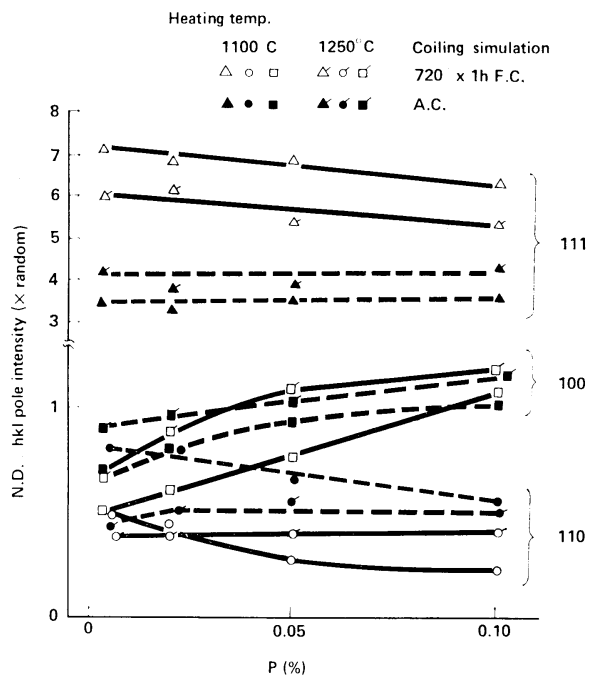

Fig. 8. Effect of Phosphorus oo pole intensity of normal $\mathrm{G}$ aluminum killed steel annealed at $800^{\circ}$ $\mathrm{C} \times 0$ min.
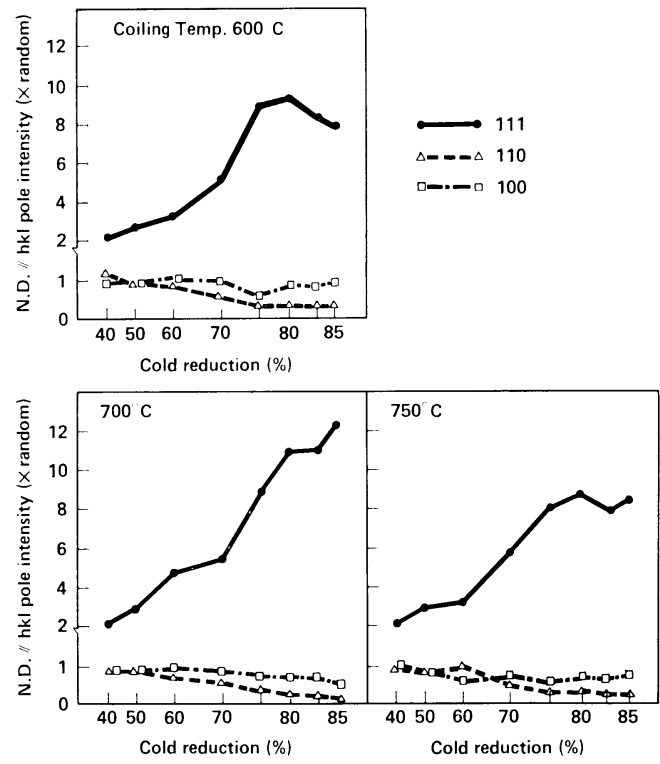

Fig. 9. Relation between hkl pole intensity and cold reduction of low-C-low $\mathrm{Mn}-\mathrm{B}-\mathrm{Phosphorus}$ steels coiled at various temperature.

リン添加鋼において高い $\bar{r}$ 值を得るにはリンの阻害作用 に勝る高純效果を生又出す必椞がある.

低 C-低 Mn-B-P 鋼は炭化物，固溶 Mn を減じ，さ らに BN とすることで占溶Nを0とすることにより，リ

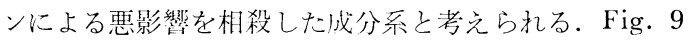
はこの鋼の各卷取洫度における面強度之冷延压下率の関 係を示す図である.Fig. 4, Fig, 9 を比較すると $\bar{r}$ 值の

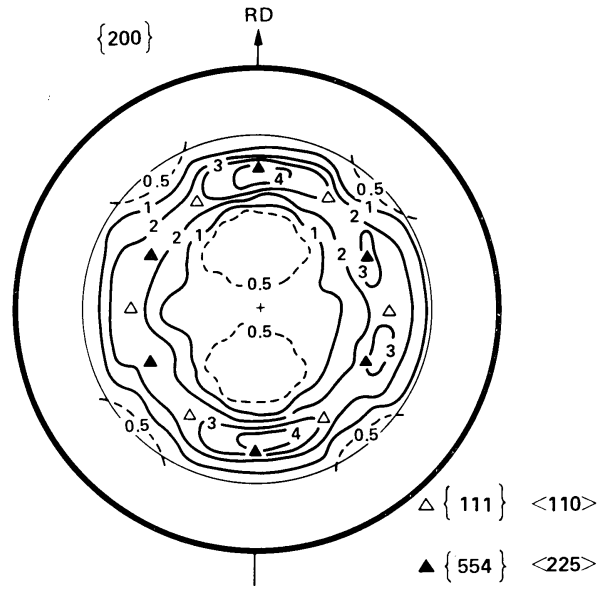

Fig. 10. Pole figure of low C-low Mn-B Phospphorus steel coiled at $700^{\circ} \mathrm{C}$, cold reduced by 80 $\%$. and annealed at $850^{\circ} \mathrm{C}$.

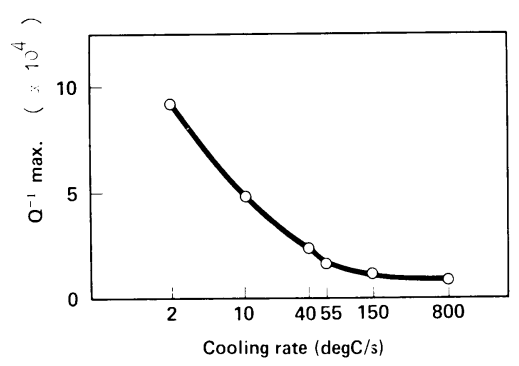

Fig. 11. Internal friction data showing the relation between the amount of solute carbon and cooling rate.

挙動之 111 および 100 の挙動はよく一致する.700, $750^{\circ} \mathrm{C}$ 卷き収り材では $85 \%$ 冷延まで $\bar{r}$ 值は增加して いるが，このように高冷延圧下率まで $\vec{r}$ 值が増大する傾 向は IF (Interstitial Free) 鋼等, 高純鋼によくみられる 特徵である ${ }^{13)}$ 。 また Fig. 10 に $700^{\circ} \mathrm{C}$ 巻き取り $-80 \%$ 冷延 $-850^{\circ} \mathrm{C}$ 焼鈍の場命の $\{200\}$ 正極点図を示吉が, \{554\}〈225〉が主方位であることがわかる.この $\{554\}$ 〈225〉型集合組織もまた高純鋼の特徴の一つである。な おりン自体にも $\{554\}\langle 225\rangle$ 型にする効果があるが，急 速加熱焼鈍の場合その效果が非常に小さいことをFig. 8 で用いた材料につき確認している.

以上からリン添加鋼に打いても低 $\mathrm{C}$ ，低 $\mathrm{Mn}, \mathrm{B}$ 添加 による高純化と高冷延压下率の組久合世によつて連続焼 鈍でも高 $\bar{r}$ 值を得ることができると考えられる。

\section{$4 \cdot 2$ 冷却条件, 特に $V_{\mathrm{C}}$ 之時効性}

連続焼鈍における冷却過程は急冷一過時効析出一常温ま での冷却からなつて掞り，この過程で固溶炭素の低減， 

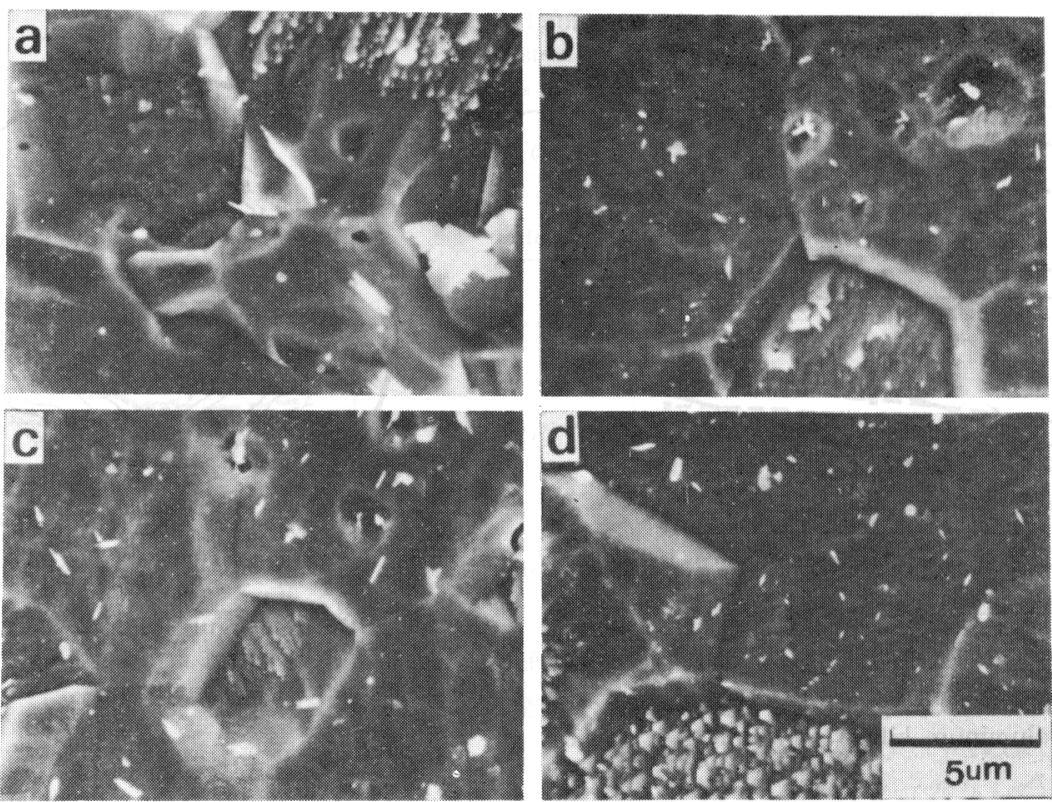

(a) $5 \mathrm{deg} \mathrm{C} / \mathrm{s}$, (b) $30 \mathrm{deg} \mathrm{C} / \mathrm{s}$, (c) $70 \mathrm{deg} \mathrm{C} / \mathrm{s}$, (d) $250 \mathrm{deg} \mathrm{C} / \mathrm{s}$

Photo. 1. Variation of cementite precipitates with cooling rate observed by the method of SPEED ${ }^{\text {7) }}$

Table 2. Calculation of Orowan stress using mean free paths which were observed by the method of SPEED.

\begin{tabular}{ccc}
\hline $\begin{array}{c}\text { Cooling rate } \\
(\operatorname{deg} \mathrm{C} / \mathrm{s})\end{array}$ & $\begin{array}{c}\lambda \\
\mu\end{array}$ & $\begin{array}{c}\Delta \tau \\
(\mathrm{MPa})\end{array}$ \\
\hline 5 & 15 & 1.4 \\
$30 \sim 70$ & $3 \sim 10$ & 3.2 \\
250 & $0.5 \sim 1$ & 28.1 \\
\hline
\end{tabular}

炭化物の形態制御を行う。窒素については高温巻き取り やボロン添加により窒化アルミニウムやボロン窒化物と して固定されている. 通常, 過時效処理は $350 \sim 400^{\circ} \mathrm{C}$ で行われる. WERT ${ }^{14)}$ によれば $\alpha$ 鉄中でセょンタイトに 平衡する固溶炭素は $400^{\circ} \mathrm{C}$ で約 $19 \mathrm{ppm}, 350^{\circ} \mathrm{C}$ で約 $11 \mathrm{ppm}$ で出り，一方，冷延鋼板飞执いて実質的飞非時 効とするには結晶粒度の影響もあるが, 固溶炭素は高々 数 $\mathrm{ppm}$ に抑觉るべきと考觉られている。このことは連 続焼鈍の炭化物析出処理は過時効帯だけではなく, その 後の常温までの冷却過程でも促進させる必要があること を意味し, 事実, 最後の数 ppm 析出は後者の過程で生 じていると考克られる.

このような析出の速度は析出核数に依存する。析出核 数は析出処理前の炭素の過飽和度に大きく影響を受け, この点から焼鈍後の泠却速度 $V_{\mathrm{C}}$ は極めて重要な要因 である,すなわち $V_{\mathrm{C}}$ が小さいと過時効処理前の固溶炭 素は少ないが析出核が少ない状態で過時効およびその後 の冷却が行われるため十分な析出が起らず，一般に過飽
和固溶炭素が多く，時効劣化が大きい.Fig. 6 に括いて $\Delta \mathrm{YP}, \Delta \mathrm{El}$ はこの傾向を示している.また，Fig. 11 は 内部摩擦測定結果を示与が, $V_{\mathrm{C}}$ の増加とともに $Q^{-1}$ max は顕著に減少する。

このように $V_{\mathrm{C}}$ が大きくなるほど固溶炭素は減少し時 効性は小さくなるが，一方， $V_{\mathrm{C}}$ が大きくなると析出核 が増し，結果亡して粒内に微細なセメンタイト析出物が 見られるようになる。この析出物によつて YP が増加 し, El が劣化することが予想される. Photo. 1 は SPEED 法によつて炭化物形態を钼察した結果である。写 真中, 白く星状に観察されるのがセメンタイトで地と晶 癖を持つている。 $V_{\mathrm{C}}$ が $5 \mathrm{deg} \mathrm{C} / \mathrm{s}$ では炭化物析出は粒 界だけであるのに対し，30，70 degC/s と $V_{\mathrm{C}}$ が増すと 粒内にも炭化物が見られるようになる。 $V_{\mathrm{C}}$ が $250 \mathrm{deg}$ $\mathrm{C} / \mathrm{s}$ に来で増すと粒内だけに炭化物が見られ，かつ非常 に微細である。この観察結果より炭化物による硬化量を OROWAN ${ }^{15)}$ にしたがつて概算してみると， Table 2 の よらになる。ただし，硬化量 $\Delta \tau$ は次式で表される.

$$
\Delta \tau=\mu b / \lambda
$$

ここに， $\mu$ は剛性率で $85000 \mathrm{MPa}, b$ はバーガース ベクトルで $2.48 \AA$ とした.

平均自由距離 $\lambda$ を SPEED 法の観察より求め, その平 均的な值を用いて計算した。. $V_{\mathrm{C}}$ が $70 \mathrm{deg} \mathrm{C} / \mathrm{s}$ 以下では $\Delta \tau$ は $5 \mathrm{MPa}$ 以下で実質上影響のない值であるが， $V_{\mathrm{C}}$ が $250 \mathrm{degC} / \mathrm{s}$ になると $\Delta \tau$ は $28 \mathrm{MPa}$ となりかなり大 
きな硬化であり当然 $\mathrm{E} 1$ の劣化もあると想される。

このように析出核数の大小による国溶苂䒺の增減と析 出苂化物门訝による硬化を考えることで， $V_{\mathrm{C}}$ には最䢛

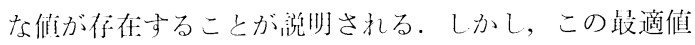
は素材成分，焼鈍渭度や，二段冷却にする場合はその条 件により影響を受けると考えられる。

\section{5. 結言}

(1) $0.015 \% \mathrm{C}-0.1 \% \mathrm{Mn}-\mathrm{B}-\mathrm{P}$ 鋼を $700{ }^{\circ} \mathrm{C}$ 卷き取

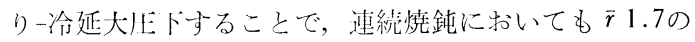
媣絞り性を存与るリン添加冷延鋼板が製造できる。

(2)この鋼板恃鈍後の冷却速度を $10 \sim 100 \operatorname{deg} \mathrm{G}$ /sとすることで，降伏点 $200 \mathrm{MPa}$ ，伸び 40\%，2\% 子ひ ずみ十塗装焼付相当処理後の強度 $300 \mathrm{MPa}$, かつ垁質的 非時効といら良好な耐デント用鋼板の性質を有する。

（3）リンは速続焼鈍の場合 $\bar{r}$ 值に対して惠影響を及 ぼすが成分，工程条件によりこれ妾補らことができる。

（4）燅鈍後の冷却速度は炭素の過飽和度を高め析出 を促進させる效果と，析出岑化物を微組にし鋼を硬化さ せるといら好ましくない効果をおよぼし，結果として冷 却速度には最適话が存在する。

\section{交献}

1) H. Hu: Texture of Crystalline Solids, 2 (1976), p. 113
2) Iron and Steel International. June(1980), p. 149

$3) K$. Toda, $H$. Gondoh, $H$. Takechi, and $M$. A BE: Stahl u. Eisen, 95 (1976) 25/26, p. 1320

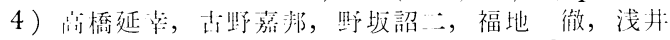
微，岩本 勉：鉄と鋼，66(1980), S 365

5 ) $K$. Toda, $H$. Gondoh, $H$. Tаkechi, $M$. AвE, $N$. Uehara, and $K$. Komiya: Trans. ISIJ, 15 (1975), p. 305

$6) H$. Kubotera, $K$, Nakaoka, $K$. Araki, $K$. Watanabe, $A$. Nishimoto, and $K$. Iwase: Trans. ISIJ, 17 (1977), p. 663

7 ) 黑澤文夫, 田口角, 谷野満: 几本金属学会会 螒，20(1981) 5，p. 377

8 ）塩川 僆男, 古㑊忠, 山崎勝二郎：日産技報, 15(1979) 12, p. 58

9 ) 阿激光延, 小甲康二, 林征夫, 速水哲愽：П本 金属学全誌, 44(1980) 1, p. 84

$10) M$. Matsuo, $H$. Hayakawa, and $S$. Hayami: "Textures of Materials", Proc. 5 th International Conference on Texture of Materials, e.d by $G$. Gottstein and $K$. Lücke (1978) Spring er-Verlag

11) 久保寺治朗, 中网一秀, 荒术健治, 渡辺馨, 㞸 瀬耕二：鉄之鍋，62(1976), p. 846

12）松藤和雄，下村隆良，大沢紘一，奥山健，木下 正行, 逢坂 忍: 日本鋼管技報, 84(1980), p. 14

13）福四过雄, 清水峯琞: 塑性と加工, 13(1972) 142, p. 1212

14) C. A. Wert: J. Metals, 188 (1950), p. 1212

15) Dislocations in Metals, AIME, New York, (1954), p. 131 